

\section{MACMILLAN TEXTS IN ECONOMICS}

Macmillan Texts in Economics is a new generation of economics textbooks from Macmillan, developed in conjunction with a panel of distinguished editorial advisers:

David Greenaway, Professor of Economics, University of Nottingham

Gordon Hughes, Professor of Political Economy, University of Edinburgh

David Pearce, Professor of Economics, University College, London

David Ulph, Professor of Economics, University College, London

\section{PUBLISHED}

International Trade Mia Mikic

Understanding the UK Economy (4th edn) Edited by Peter Curwen

Environmental Economics Nick Hanley, Jason F. Shogren and Ben White

Public Sector Economics Stephen Bailey

Economics of the Labour Market David Sapsford and

Zafiris Tzannatos

Business Economics Paul R. Ferguson, Glenys J. Ferguson and

R. Rothschild

International Finance Keith Pilbeam

\section{FORTHCOMING}

Future Macmillan Texts in Economics cover the core compulsory and optional courses in economics at first-degree level and will include:

Macroeconomics Eric Pentecost

Econometrics Ian D. McAvinchey 


\section{BUSINESS \\ ECONOMICS}

\section{The Application of Economic Theory}

Paul R. Ferguson, Glenys J. Ferguson and R. Rothschild

palgrave 


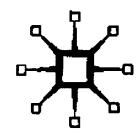

(C) Paul R. Ferguson, Glenys J. Ferguson and R. Rothschild 1993

All rights reserved. No reproduction, copy or transmission of this publication may be made without written permission.

No paragraph of this publication may be reproduced, copied or transmitted save with written permission or in accordance with the provisions of the Copyright, Designs and Patents Act 1988, or under the terms of any licence permitting limited copying issued by the Copyright Licensing Agency, 90 Tottenham Court Road, London WIT 4LP.

Any person who does any unauthorised act in relation to this publication may be liable to criminal prosecution and civil claims for damages.

The authors have asserted their rights to be identified as the authors of this work in accordance with the Copyright, Designs and Patents Act 1988.

Published by

PALGRAVE

Houndmills, Basingstoke, Hampshire RG21 6XS and

175 Fifth Avenue, New York, N. Y. 10010

Companies and representatives throughout the world

PALGRAVE is the new global academic imprint of St. Martin's Press LLC Scholarly and Reference Division and

Palgrave Publishers Ltd (formerly Macmillan Press Ltd).

ISBN 978-0-333-54247-7

ISBN 978-1-349-22696-2 (eBook)

DOI 10.1007/978-1-349-22696-2

This book is printed on paper suitable for recycling and made from fully managed and sustained forest sources.

A catalogue record for this book is available from the British Library.

$\begin{array}{rrrr}12 & 11 & 10 & 9 \\ 06 & 05 & 04 & 03\end{array}$

\section{Series Standing Order (Macmillan Texts in Economics)}

If you would like to receive future titles in this series as they are published you can make use of our standing order facility. To place a standing order please contact your bookseller or, in case of difficulty, write to us at the address below with your name and address, the title of the series and the ISBN quoted above.

Customer Services Department, Macmillan Distribution Ltd Houndmills, Basingstoke, Hampshire RG21 6XS, England 


\section{To our parents \\ (Paul and Glenys Ferguson)}

To my father and the memory of my mother

(R. Rothschild) 


\section{Contents}

List of Figures

List of Tables

Acknowledgements

Chapter 1: Introduction

1.1 Distinguishing Features of this Book

1.2 Target Audience

1.3 An Overview of the Content

1.4 What the Book Omits

1.5 Use of the Book

Chapter 2: Firms and Markets: Identifying the Optimal Boundary

2.1 Introduction

2.2 What is a Firm?

2.3 Firms and Markets as Means of Allocating Resources

2.4 Economic Coordination by the Firm or by the Market?

2.5 The Linkage Approach

2.6 Ways of Changing the Boundary of the Firm

2.7 Intermediate Forms of Organisation

2.8 Conclusion

Chapter 3: The Organisation of the Firm: Efficiency, Incentives and Controls

3.1 Introduction

3.2 Management Characteristics and Organisation

3.3 Owners versus Managers

3.4 Conclusion

Chapter 4: Operations and Costs: The Core of the Conversion Process

4.1 Introduction

4.2 The Conversion Process $\mathbf{x}$

xiii

$\mathrm{xv}$

14.3 Technical Relationships Between Inputs and Outputs

4.4 Production and Costs in the Short Run 48

4.5 Costs in the Long Run 54

4.6 Factors Causing Costs to Fall 59

4.7 Linear Programming 65

4.8 Conclusion

7 Chapter 5: The Costs of Support

7 Activities: The Neglected Costs

$8 \quad 5.1 \quad$ Introduction 71

5.2 Support Activities $\quad 72$

$9 \quad 5.3 \quad$ Stock Costs $\quad 76$

5.4 Viewing the Organisation as a

Whole $\quad 80$

5.5 Costs Related to the External

Environment

87

88

24

28

Chapter 6: Cost Identification: Accounting Versus Economic Perspectives 90

6.1 Introduction 90

6.2 Availability of Information for

Costing

6.3 Product Costing Systems 92

6.4 Opportunity Cost 100

6.5 Conclusion 104

Chapter 7: Financial Control: Constraints on Management

106

7.1 Introduction 106

$42 \quad 7.2$ Shareholders' Objectives 107

$42 \quad 7.3$ Use of Financial Information for

43

Monitoring and Control 
7.4 Financial Controls on the Management Team as a Whole

7.5 Conclusion

Chapter 8: Investment: Increasing the Value of the Firm

8.1 Introduction

8.2 Appraisal of Investment Proposals

8.3 Problems Associated with Investment Appraisal

8.4 Investment in Milk Quota

8.5 The Finance of Investment

8.6 Conclusion

Chapter 9: Demand: Understanding the Customer and the Market

9.1 Introduction

9.2 The Basis of Demand

9.3 Factors Influencing Demand

9.4 Elasticity of Demand

9.5 Estimating Demand

9.6 Forecasting Demand

9.7 The Characteristics Approach to Demand Analysis

9.8 Market Segmentation

9.9 Advertising

9.10 Brands

9.11 Conclusion

Chapter 10: Competition and Monopoly:

Responding to the Competitive

Environment

10.1 Introduction

10.2 The Nature and Implications of Market Structure

10.3 Perfect Competition

10.4 Monopoly

10.5 Monopolistic Competition

10.6 Identifying Market Structure

10.7 How May Firms Alter Their Competitive Environment?

10.8 Conclusion

Chapter 11: Oligopoly: Living with Rivals 11.1 Introduction

11.2 A Hypothetical Problem

11.3 Strategy and Game Theory
11.4 Noncooperative Behaviour in Oligopoly

201

$\begin{array}{lll}11.5 & \text { Tacit Collusion } & 204 \\ 11.6 & \text { Tacit Collusion: Price Leadership } & 207\end{array}$

11.7 Collusive Behaviour: Cartels 210

120

120

121

11.8 Strategies to Deter Entry

213

11.9 Effecting Entry into a New Market

215

11.10 Undertakings to Customers

11.11 Conclusion

217

218

Chapter 12: Corporate Strategy: Acquiring and Sustaining Competitive Advantage

12.1 Introduction

12.2 What is a Corporate Strategy?

12.3 Devising a Corporate Strategy 221

12.4 The Strategic Core

222

12.5 Analysis of the Environment

226

12.6 Choosing a Corporate Strategy 228

12.7 Implementing a Corporate Strategy 236

12.8 Sustaining Competitive Advantage 241

12.9 Adapting a Corporate Strategy 244

12.10 The Strategy of IKEA 245

12.11 Conclusion

Chapter 13: Government and the Firm:

The Impact of Economic Management

13.1 Introduction

13.2 Reasons for Economic Management

13.3 Government Provision of Goods and Services

13.4 State Regulation

13.5 Privatisation 257

13.6 Macroeconomic Policy 259

171

13.7 Regional Policy

260

263

265

266

182

184

188

194

Trade Policy

13.9 Government Failure

13.10 Conclusion

Chapter 14: Competition Policy: Government Regulation of Competitive Behaviour

14.1 Introduction

197
14.2 The Economic Basis for Competition Policy

14.3 Competition Policy in the UK and EC

14.4 Monopoly Policy 
14.5 Merger Policy

14.6 Restrictive Practices

14.7 Anti-Competitive Practices

14.8 Public Bodies

14.9 Direct Support to Firms

14.10 Conclusion

A14.1 The Evolution of UK Competition Policy Legislation

A14.2 Definition of the Public Interest in the UK

A14.3 Articles 37, 85 and 86 of the EEC Treaty

Chapter 15: The Natural Environment:

Problems and Opportunities

15.1 Introduction

15.2 Firms and the Natural Environment

15.3 Policy to Control Pollution

15.4 Resource Conservation

15.5 Government Failure Revisited

15.6 Conclusion

Chapter 16: Case Study: The Airline

Industry

16.1 Introduction

16.2 Firms and Markets

16.3 Airline Organisation

16.4 Costs

16.5 Financial Control

16.6 Investment Appraisal

16.7 Demand

16.8 The Competitive Environment

16.9 Airlines' Strategies

16.10 Governments and the Airline Industry

16.11 Regulation of the Airline Industry

16.12 Privatisation of the Airline Industry

16.13 The Future of the Airline Industry
276

279

282

282

283

284

284

285

285

287

287

287

290

298

306

306

308

308

309

318

320

331

333

334

341

352

359

364

367

370
Appendices

Appendix A1: Ethical Considerations $\quad 374$

A1.1 Introduction $\quad 374$

A1.2 Ethical Systems $\quad 374$

A1.3 Market Economics $\quad 375$

A1.4 Social Responsibility of Firms $\quad 378$

Appendix A2: Regression $\quad 379$

A2.1 Introduction $\quad 379$

A2.2 Linear Regression $\quad 379$

A2.3 Regression: An Illustration $\quad 379$

A2.4 Statistical Tests 381

Appendix A3: Empirical Cost Functions 384

A3.1 Introduction 384

A3.2 The Engineering Approach 384

A3.3 Statistical Techniques 385

A3.4 Survivor Technique $\quad 390$

A3.5 Conclusion

391

Appendix A4: Investment Appraisal and

the Preferences of Shareholders

392

A4.1 Introduction

392

A4.2 Robinson Crusoe

392

A4.3 Implications for Managers 396

A4.4 Conclusion

397

Appendix A5: The Cost of Capital 398

A5.1 Introduction 398

A5.2 Capital Asset Pricing Model 398

A5.3 The Cost of Equity Finance 399

A5.4 The Cost of Loan Finance 400

A5.5 The Cost of Capital 400

References $\quad 402$

Index of Companies $\quad 405$

Index of Subjects

409 


\section{List of Figures}

Figure 2.1 Coordination of economic activity through the market

Figure 2.2 Economic coordination by both firms and markets

Figure 2.3 The firm versus the market: the effect of asset specificity

Figure 2.4 Knowledge links within a firm

Figure 2.5 Linkages between the three products

Figure 3.1 The U-form management hierarchy

Figure 3.2 Hierarchy and the U-form firm

Figure 3.3 The M-form management hierarchy

Figure 3.4 Costs of management

Figure 4.1

Figure 4.2 The firm and its environment Production relationships for Galgate Electrical

Figure 4.3 Isoquants for Galgate Electrical

Figure 4.4 The short-run production function

Figure 4.5 Output variation in the short run

Figure 4.6 Behaviour of total costs in the short run

Figure 4.7 Behaviour of average and marginal costs in the short run

Figure 4.8 Isocost lines

Figure 4.9 Output variation in the long run

Figure 4.10 Constant long-run average costs

Figure 4.11 Returns to scale

Figure 4.12 Development costs per unit of output

Figure 4.13 Experience curves
11

14

Figure 4.14 Experience curves for Liberty

Ship production

63

Figure 4.15 Experience curves and the first-mover advantage

Figure 4.16 Experience curves and the first-mover advantage negated

Figure 4.17 The empirical or 'engineering' production function for Galgate Electrical

Figure 4.18 Feasible input combinations

Figure 4.19

The isoprofit curve

Figure 4.20

Solution to Galgate's decision problem

Figure 5.1

A simple firm

Figure 5.2

The conversion process

Figure 5.3

The effects of transport costs

Figure 5.4

The holding of stocks in a manufacturing firm

Figure 5.5

Level of stock holdings

Figure 5.6

Optimal order quantity

Figure 5.7

Reductions in inventory

73

75

Figure 5.8

The Kanban system

Figure 5.9

JIT/TQM production

Figure 6.1

The optimal amount of information

Figure 6.2 An absorption costing system

Requirements of an effective control system

Figure 7.2 Manager versus shareholder preferences

Figure 8.1

Comparison between the net present value and the internal rate of return

Figure 8.2 The relationship between the net present value and the internal rate of return

Figure 8.3 Attitudes towards risk

Figure 8.4 Variability of project returns 130 131 
Figure 8.6 Sensitivity analysis

Figure 8.7 A decision tree

Figure 8.8 The value of milk quota under different assumptions

Figure 8.9 The firm's cost of capital traditional view

Figure 8.10 The firm's cost of capital Modigliani and Miller view

Figure 8.11 Project selection with capital rationing

Figure 9.1 A linear demand curve

Figure 9.2 The demand curve

Figure 9.3 Arc price elasticity of demand

Figure 9.4 Elasticity varies along a linear demand curve

Figure 9.5 Demand, price elasticity, total and marginal revenue

Figure 9.6 High and low price elasticity of demand

Figure 9.7 Income elasticity of demand

Figure 9.8 The identification problem

Figure 9.9 The product life cycle

Figure 9.10 The characteristics approach

Figure 9.11 Combining two varieties

Figure 9.12 Preference distributions

Figure 9.13 Segmentation of the market for lawnmowers

Figure 9.14 Methods of market segmentation

Figure 9.15 Type of good and the importance of advertising

Figure 9.16 Consumer product awareness

Figure 10.1 Market structure, behaviour and performance

Figure 10.2 Cost, revenue and profit for a perfectly competitive firm

Figure 10.3 Perfect competition

Figure 10.4 Cost, revenue and profit for a monopolist

Figure 10.5 Profit maximisation in monopoly

Figure 10.6 Third-degree price discrimination

Figure 10.7 Second-degree price discrimination

Figure 10.8 First-degree price discrimination

Figure 10.9 Peak and off-peak prices
Figure 10.10 Pricing of joint products

182

Figure 10.11 The two demand curves in monopolistic competition

183

Figure 10.12 Entry into monopolistic competition

Figure 10.13 Long-run equilibrium in monopolistic competition

Figure 10.14 A producers' association to restrict output

Figure 10.15 The variety spectrum

Figure 10.16 Advertising of one variety

Figure 10.17 Advertising of all varieties

Figure 11.2 Noncooperative versus cooperative behaviour

203

Figure 11.3 The kinked demand curve

204

Figure 11.4 Cost-based price

determination

206

Figure 11.5 Barometric price leadership

208

Figure 11.6

Dominant-firm price leadership

208

Figure 11.7 An increase in wages by the dominant firm

Figure 11.8 A cartel

Figure 11.9 Profitable cheating in a cartel

Figure 12.1 Strategic analysis, choice and implementation

Figure 12.2 The strategic core

Figure 12.4 Factors influencing the boundary of a firm

Figure 12.5 The external environment of the firm

Figure 12.6 The Boston box

Figure 12.7 Distribution of preferences and products in a market

Figure 12.8 The value chain

Figure 12.9 Porter's generic strategies leaders and followers

Figure 12.12 The overall value system Figure 12.13 Controlling competitor response

Figure 12.14 Strategic and environmental change

Figure 13.1 Concepts of efficiency 
Figure 13.2 Productive efficiency

Figure 13.3 The public good argument for market failure

Figure 13.4 Natural monopoly

Figure 13.5 The effect of a tariff

Figure 13.6 The effect of a quota

Figure 14.1 The effect of monopoly on economic welfare

Figure 14.2 The organisation of UK competition policy 1992

Figure 14.3 Merger control policy in the EC and UK 1992

Figure 15.1 Pollution: a negative externality

Figure 15.2 An environmental standard

Figure 15.3 An inappropriate standard and penalty

Figure 15.4 Environmental standards and the costs of pollution abatement

Figure 15.5 Taxation to reduce pollution

Figure 15.6 The market for pollution permits

Figure 15.7 Allocation of a finite resource stock

Figure 15.8 Optimal depletion over timethe competitive industry

Figure 15.9 Fish biology

Figure 15.10 Relationships between fishing stock, effort and catch size

Figure 15.11 The relationship between fishing effort and catch

Figure 15.12 The equilibrium level of fishing

Figure 16.1 The scheduled airline and its environment

Figure 16.2 Knowledge links within an airline
251

252

253

264

264

269

272

277

290

293

293

294

295

297

300

302

303

303

304

304

311

312
Figure 16.3 The organisational structure of Swissair

Figure 16.4 The organisational structure of KLM

Figure 16.5 Short-run costs of a particular flight

Figure 16.6 Linear routes compared with

Figure 16.7 Changes in the USA since deregulation

Figure A1.1 The efficiency of the market equilibrium

376

Figure A2.1 Least-squares regression of demand on price

380

Figure A2.2 A least-squares regression with crucial variables omitted 381

Figure A3.1 The shape of the empirical long-run average operations cost curve

Figure A3.2 A linear empirical cost function

387

Figure A3.3 Quadratic and cubic empirical cost functions

387

Figure A3.4 Long-run average cost function using the survivor technique

391

Figure A4.1 Inter-temporal choice

392

Figure A4.2 Crusoe's production possibility frontier

Figure A4.3 Crusoe's investment and consumption decision

Figure A4.4 The introduction of a financial market

Figure A5.1 Consumer preferences between risk and rates of return

399

Figure A5.2 Individual preferences between risk and return 


\section{List of Tables}

Table 2.1 Markets versus firms: factors influencing relative efficiency

Table 2.2 Characteristics of three hypothetical products

Table 2.3 Main motives for mergers and joint ventures, 1986/7

Table 4.1 The production function for Galgate Electrical

Table 4.2 The short-run relationship between inputs and outputs

Table 4.3 Short-run costs

Table 6.1 Cost report for product $Y$

Table 6.2 Activity-based costing at Hewlett-Packard (PC Board Type 67)

Table 6.3 Costs of the proposed mine

Table 7.1 Budget for a hypothetical training department

Table 7.2 The mechanics of takeovers

Table 8.1 Net present value method assuming a 10 per cent cost of capital

Table 8.2 Finding the internal rate of return

Table 8.3 The traditional view of the cost of capital

Table 8.4 Capital rationing and the profitability index

Table 9.1 Calculating point price elasticity

Table 10.1 Structural features of five hypothetical markets

Table 11.1 A dominant strategy for both players

Table 11.2 A dominant strategy for one player

Table 11.3 No dominant strategy

Table 11.4 No Nash equilibrium

Table 115 More than one Nash equilibrium
Table 11.6 Payoffs to competition in output

Table 11.7 Game theory analysis and the kinked demand curve

Table 11.8 The kinked demand curve with a different payoff structure

Table 11.10 A credible threat that is not credible

Table 11.13 Entry is not a credible threat

Table 11.14 Subsidy makes entry a credible

Table 11.15 Entry is not a credible threat, despite subsidy

Table 11.16 Both firms have an incentive to price low

Table 11.17 Undertakings give an incentive to price high

Table 11.18 Price-equalising discounts give an incentive to price high

Table 12.1 Links with economic theory

Table 14.1

Competition powers of the

European Community as given in the Treaty of Rome

Table 15.1 The fisherman's view of payoffs to effort

Table 16.1 The largest scheduled passenger airlines 1990

Table 16.2 The scheduled services of KLM 310

Table 16.3 Percentage distribution of costs

Table 16.4 Airline labour costs and

200 Table 16.5 Opportunities for economies of scale and scope

Table 16.6 Scheduled air travel 1980-90 
Table 16.7 Changes in traffic by geographical area served by European airlines

Table 16.8 Load factors on scheduled services of UK airlines 1990

Table 16.9 International city pairs with highest scheduled passenger traffic 1988

Table 16.10 Passengers embarked and disembarked by airport 1989

Table 16.11 Whether to offer free drinks

Table 16.12 Reaction of incumbent airlines to new entry
Table A3.1 Cost and output data for Company $Z$

335 Table A3.2 Results of the cost analysis 389

Table A3.3 Market share by firm size: the US steel industry 390

Table A4.1 Investment opportunities facing Robinson Crusoe 393

342 Table A4.2 Crusoe's problem at point $A \quad 394$

Table A4.3 Crusoe's problems at point $D \quad 396$

343 Table A4.4 Crusoe's solution 396

345 Table A4.5 Shareholders' marginal time preference rates and the firm's cost of capital 


\section{Acknowledgements}

Three names on the cover imply that this book is solely the result of those people's efforts. They are simply the ones who pick up the credit or receive the brickbats. Without the efforts of many others this book would have contained more errors and appeared at a later date on the bookshelves. As with most books, the authors have used up any accumulated goodwill, called on previous favours or drawn on family ties. Invariably requests for help have met with a generous response. The book is much improved by the dedication and attention to detail of other people.

Hilda Ferguson and Ron Bowen, with their nontechnical backgrounds, helped with the quality of the English and the clarity of the explanations. Robert Read provided technical help with the chapters on the firm and corporate strategy, whilst Charlie Wilkinson performed a similar role on the finance chapters. Ex-MBA students Stuart Schofield, Laura Rowe and Justin Pannell provided particularly valuable advice on the case study of the airline industry. The authors wish to give special mention to Gerry Steele for the count- less hours he spent poring over drafts at all stages of the book's gestation. His main contribution has been to remove redundant words and to ensure that ideas are expressed as clearly and concisely as possible. Despite the attention of all these individuals, errors will still remain for which the authors accept full responsibility.

Whilst this book is ultimately a collaborative effort, readers may be interested in the contributions by individuals. $\mathrm{R}$. Rothschild wrote most of Competition and Monopoly, all of Oligopoly and helped with Operations and Costs and Demand. $\mathrm{He}$ also wrote the appendix on Regression. Glenys Ferguson wrote part of Demand, contributed to Competition and Monopoly and was jointly responsible, with Paul Ferguson, for the airline case study. She also contributed to The Natural Environment, provided many of the real-world examples and was responsible for the general integration and consistency of the material throughout the book. The rest of the book is principally the work of Paul Ferguson.

\section{Lancaster \\ England}

Paul R. Ferguson

GLENYS J. FERGUSON

R. ROTHSCHILD

The authors and publishers are grateful to the following for permission to reproduce copyright material:

The Free Press, a division of Macmillan Inc., for a diagram from The Economic Institutions of Capitalism by Oliver E. Williamson, copyright (C) 1985 by Oliver E. Williamson; for a diagram from Japanese Manufacturing Techniques by Richard J. Schonberger, copyright (C) 1982 by Richard J. Schonberger; for diagrams from Competitive Advantage: Creating and Sustaining Superior Performance by Michael E. Porter, copyright (C) 1985 by Michael E. Porter; for a diagram from Competitive Strategy: Techniques for Analyzing Industries and Competitors by Michael E. Porter, copyright (C) 1980 by The Free Press. 
Prof J. Cable for a diagram from 'Organisational Forms and Economic Performance' in S. Thompson and M. Wright (eds), Internal Organisation, Efficiency and Profit (Philip Allan, 1988).

Harvard Business Review for an exhibit from 'How Hewlett-Packard Gets Numbers it Can Trust' by D. Berlant, R. Browning and G. Foster, Jan./Feb. 1990, copyright (C) 1990 by the President and Fellows of Harvard College, all rights reserved.

Economic Policy journal for a table from F. McGowan and P. Seabright, 'Deregulating European Airlines', vol. 9, 1989.

The University of Chicago Press for a table from 'The Economies of Scale' by G. J. Stigler, Journal of Law and Economics, vol. 1 (1958).

Every effort has been made to contact all the copyright-holders, but if any have been inadvertently overlooked the necessary arrangement will be made at the earliest opportunity. 